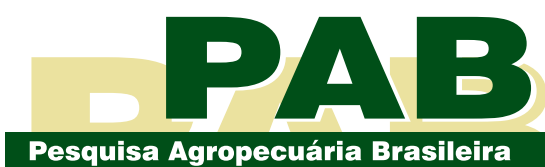

ISSN 1678-3921

Journal homepage: www.embrapa.br/pab

For manuscript submission and journal contents, access: www.scielo.br/pab

\section{Nitrogen management of forage grasses for nutrition, seed production, and nutrients in residual straw}

\begin{abstract}
The objective of this work was to evaluate the nutrition, accumulation of nutrients in residual straw, pure seed yield, and seed quality of the tropical forage grasses 'Mombaça' and 'Xaraés' subjected to topdressing with nitrogen fertilizer management. Field experiments were carried out in the municipalities of Rancharia and Presidente Prudente, in the state of São Paulo, Brazil. The treatments included a control (without $\mathrm{N}$ topdressing) and four $\mathrm{N}$ fractionation forms at different forage stages: $150 \mathrm{~kg} \mathrm{ha}^{-1} \mathrm{~N}$, at the vegetative phase (VP); $150 \mathrm{~kg} \mathrm{ha}^{-1} \mathrm{~N}$, at the beginning of the reproductive phase (RP), between panicle initiation and the prebooting stages; $100 \mathrm{~kg} \mathrm{ha}^{-1} \mathrm{~N}$, at VP plus $50 \mathrm{~kg} \mathrm{ha}^{-1} \mathrm{~N}$ at RP; and $50 \mathrm{~kg} \mathrm{ha}^{-1} \mathrm{~N}$ at VP plus $100 \mathrm{~kg} \mathrm{ha}^{-1} \mathrm{~N}$ at RP. Fertilization with $\mathrm{N}$ as topdressing, regardless of the $\mathrm{N}$ fractionation form, increased $\mathrm{N}$ concentration in the flag leaf and in residual straw, and the quantities of $\mathrm{N}$ accumulated by 'Mombaça' and 'Xaraés' forage grasses. The application of all or most N in the VP increased the quantities of residual straw and of $\mathrm{P}$ and $\mathrm{K}$ accumulated by the 'Mombaça' forage grasses. The application of all or most $\mathrm{N}$ in the RP provided a greater pure seed yield and $\mathrm{N}$ use efficiency in both forage grasses. The seed physiological quality of the forages is not affected by fertilization with $\mathrm{N}$ topdressing.
\end{abstract}

Index terms: Megathyrsus maximus, Urochloa brizantha, nitrogen fertilization, nutrient accumulation, time of application.

\section{Manejo do nitrogênio em gramíneas forrageiras quanto à nutrição, produção de sementes e nutrientes na palhada residual}

Resumo - O objetivo deste trabalho foi avaliar a nutrição, a quantidade de nutrientes na palhada residual, a produtividade de sementes puras e a qualidade de sementes das gramíneas forrageiras tropicais 'Mombaça' e 'Xaraés', quando submetidos ao manejo de nitrogênio em cobertura. Foram conduzidos experimentos em campo nos municípios de Rancharia e de Presidente Prudente, no Estado de São Paulo. Os tratamentos consistiram de uma testemunha (sem $\mathrm{N}$ em cobertura) e quatro formas de fracionamento de $\mathrm{N}$, em diferentes estádios das gramíneas: $150 \mathrm{~kg} \mathrm{ha}^{-1}$ de $\mathrm{N}$, na fase vegetativa (VP); $150 \mathrm{~kg}$ $\mathrm{ha}^{-1}$ de N, no início da fase reprodutiva (RP), entre os estádios de iniciação floral e emborrachamento; $100 \mathrm{~kg} \mathrm{ha}^{-1}$ de N na VP e $50 \mathrm{~kg} \mathrm{ha}^{-1}$ na RP; e $50 \mathrm{~kg}$ $\mathrm{ha}^{-1}$ de N na VP e $100 \mathrm{~kg} \mathrm{ha}^{-1}$ na RP. A adubação nitrogenada em cobertura, independentemente da forma do fracionamento de $\mathrm{N}$, resultou em aumento da concentração de N, na folha-bandeira e na palhada residual, e das quantidades de N acumulado pelas forrageiras 'Mombaça' e 'Xaraés'. A aplicação de todo ou da maior parte de N na VP aumentou a quantidade de palhada residual e de P e K acumulados pela gramínea 'Mombaça'. A aplicação de todo ou da maior parte do N na RP proporcionou maior produtividade de sementes puras e eficiência de uso do $\mathrm{N}$ em ambas as forrageiras. A qualidade fisiológica das sementes das forrageiras não é afetada pela adubação nitrogenada de cobertura.

Termos para indexação: Megathyrsus maximus, Urochloa brizantha, adubação nitrogenada, acúmulo de nutrientes, época de aplicação. 


\section{Introduction}

Brazil is the largest seed producer of tropical forage grass worldwide, with an emphasis on Megathyrsus maximus (Jacq.) B.K. Simon \& S.W.L. Jacobs (Syn. Panicum maximum Jacq.) and Urochloa brizantha (Hochst. ex A. Rich.) R.D. Webster [Syn. Brachiaria brizantha (A. Rich) Stapf], which have a caespitose growth, an erect habit, and a high-forage yield potential (Corrêa \& Santos, 2003). According to Batello et al. (2017), the demand for tropical forage grass seeds will increase over the coming years due to the export to Africa, Australia, and Latin America, primarily for use in pasture restoration and croplivestock integrated systems. Estimates from the last agricultural census of 2006 indicated that the total pasture area (natural and cultivated) in Brazil is 172.3 million hectares (IBGE, 2006). About $60 \%$ of this total is in some process of degradation and requires restoration (Cecato et al., 2014).

In recent years, there have been significant increases in the prices of forage grass seeds in Brazil (Cepea, 2017). This occurred because of the high demand and low supply of seeds in the market caused by the decline of seed yield, especially due to adverse climatic conditions and to the lack of technical information on the management and fertilization of tropical forage grasses for seed production. The primary objective of the fertilization programs of tropical forage grasses in Brazil is to increase the development of vegetative structures (vegetative tillers and leaves) (Barcelos et al., 2011; Cecato et al., 2014). However, for seed production, the development of the reproductive structures (reproductive tillers, flowers, and seeds) should be prioritized, and this has resulted in questions about the proper management of fertilization, primarily for nitrogen (Nery et al., 2012; Catuchi et al., 2013; 2017).

Nitrogen is one of the nutrients that accumulates in high amounts in the aboveground tropical perennial forage grasses (Primavesi et al., 2006; Moreira et al., 2013; Costa et al., 2015). Nitrogen supply to tropical forage grasses increases herbage yield, as well as the yield components (number of reproductive tillers, inflorescence, length, numbers of seed per inflorescence, and seed filling), seed yield (Manarim \& Monteiro, 2002; Barth Neto et al., 2010; Canto et al., 2012; Catuchi et al., 2017), and seed quality (weight and germination) (Canto et al., 2012; Catuchi et al., 2017). However, excess
$\mathrm{N}$ supply or its application at inappropriate development phases can reduce the yield and quality of tropical forage grass seeds (Condé \& Garcia, 1988; Barth Neto et al., 2010; Catuchi et al., 2017).

According to Peres et al. (2010), high-N rates $\left(>100 \mathrm{~kg} \mathrm{ha}^{-1}\right)$ in the initial phase of the development of tropical forage grasses may cause excessive vegetative growth and reduce the reproductive development. This occurs because plants allocate nutrients for vegetative biomass production (Condé \& Garcia, 1988; Viana et al., 2011; Cecato et al., 2014). Therefore, to increase the production of tropical forage grass seeds, the application of part of $\mathrm{N}$ at the beginning of the reproductive phase (after panicle initiation) may be advantageous, since in this phase, the source-sink ratio of the plant occurs, and photoassimilates, which would previously be translocated to the growth of tillers and leaves, are redistributed to the reproductive structures (Condé \& Garcia, 1988; Basto, 2014; Catuchi et al., 2017).

Factors such as species, cultivar, and nutrient availability may influence the aboveground dry matter (DM) production and nutrient accumulation in the DM of tropical forage grasses (Primavesi et al., 2006; Moreira et al., 2013; Catuchi et al., 2017). The aboveground residual straw of tropical forage grass seed production, which can reach $15-20 \mathrm{Mg} \mathrm{ha}^{-1}$ (Souza et al., 2006; Catuchi et al., 2017), can be harvested to produce hay for animal feed, avian beds, the production of organic compounds, and burning for energy cogeneration, or it can be left on soil surface, primarily in areas managed in the no-till system for grain crop cultivation (Souza et al., 2006). Therefore, information on the amount of nutrients contained in the aboveground residual straw is essential to adequately manage fertilizer for forage grasses present in the area, as well as for subsequent crops, to maintain the soil organic matter, adequate nutrient supply, and to avoid soil exhaustion in the areas from which residual straw is removed. However, information is lacking on the most appropriate management of $\mathrm{N}$ for seed production, and on how it affects the accumulation of nutrients in the aboveground biomass (residual straw) of the primary species and cultivars of tropical perennial forage grasses used in Brazil.

The objective of this work was to evaluate the nutrition, accumulation of nutrients in the aboveground residual straw, pure seed yield, and seed quality of the 
tropical forage grasses 'Mombaça' and 'Xaraés', as a consequence of topdressing $\mathrm{N}$ fertilizer management.

\section{Materials and Methods}

Two field experiments were carried out, one with 'Mombaça' in the Canelão farm, in the municipality of Rancharia $\left(50^{\circ} 53^{\prime} \mathrm{W}, 22^{\circ} 07 \mathrm{~S}\right.$, at $540 \mathrm{~m}$ altitude), and other with 'Xaraés' ('CIAT 26110', 'BRA 004308') at the experimental station of the Universidade do Oeste Paulista, in the municipality of Presidente Prudente $\left(51^{\circ} 26^{\prime} \mathrm{W} ; 22^{\circ} 07^{\prime} \mathrm{S}\right.$, at $418 \mathrm{~m}$ altitude), both located in the state of São Paulo, Brazil. According to the classification of Köppen-Geiger, the predominant climate in the region is Aw, with a hot and rainy season between October and March, and a dry season between April and September. Rainfall and temperature were measured daily, during the experimental periods (Figure 1).
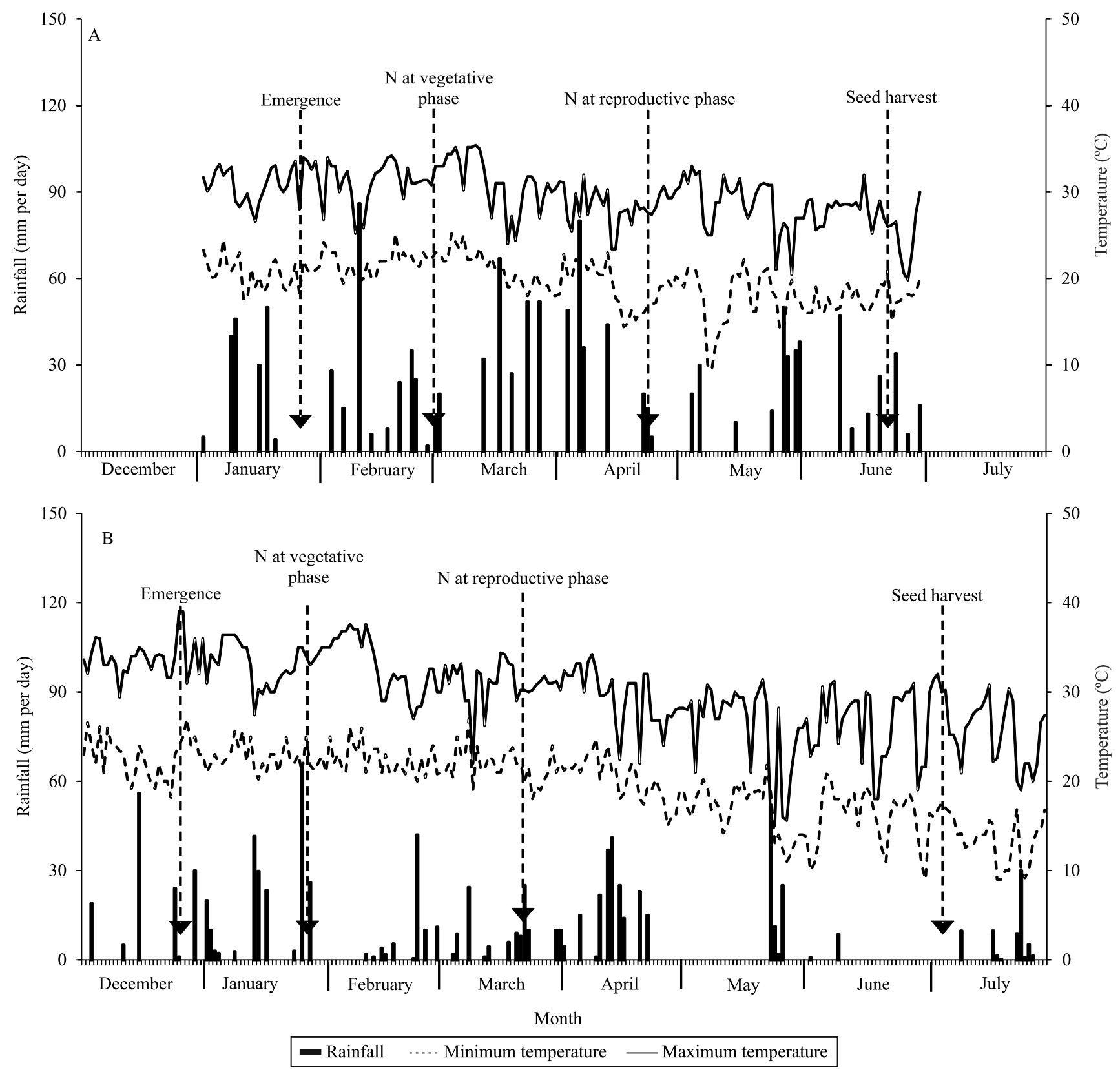

Figure 1. Daily rainfall, and maximum and minimum temperatures recorded in the experimental areas: A, experiment with Megathyrsus maximus 'Mombaça' from January to June 2013; B, experiment with Urochloa brizantha 'Xaraés' from December 2013 to July 2014. Arrows indicate the forage grasses management performed. 
The experiment with 'Mombaça' was performed in a Latossolo Vermelho-Amarelo distrófico with a medium sandy texture, while 'Xaraés' experiment was performed in an Argissolo Vermelho-Amarelo distrófico with a medium sandy texture (Santos et al., 2013). Samples were collected at $0-20 \mathrm{~cm}$ soil depth, before the implementation of the experiments, and subjected to analysis for their chemical characteristics (Table 1). These analyses indicated that in both sites the availability of $\mathrm{P}, \mathrm{K}, \mathrm{Ca}$, and $\mathrm{Mg}$ was appropriate for the cultivation and seed production of the tropical forage grasses.

The experiments were carried in a randomized complete block design with four replicates. The treatments included a control (without $\mathrm{N}$ topdressing), and four fractionation forms of topdressing $\mathrm{N}$ fertilization $\left(150 \mathrm{~kg} \mathrm{ha}^{-1} \mathrm{~N}\right.$ at the vegetative phase (VP); $150 \mathrm{~kg} \mathrm{ha}^{-1} \mathrm{~N}$ at the beginning of the reproductive phase (RP), between panicle initiation and prebooting stages); $100 \mathrm{~kg} \mathrm{ha}^{-1} \mathrm{~N}$ at the VP, plus $50 \mathrm{~kg} \mathrm{ha}^{-1} \mathrm{~N}$ at the RP; and $50 \mathrm{~kg} \mathrm{ha}^{-1} \mathrm{~N}$ at the VP, plus $100 \mathrm{~kg} \mathrm{ha}^{-1} \mathrm{~N}$ at the RP). The rate of $150 \mathrm{~kg} \mathrm{ha}^{-1}$ of $\mathrm{N}$ was applied according to the literature (Condé \& Garcia, 1988; Barth Neto et al., 2010; Peres et al., 2010; Canto et al., 2012). All N was applied as surface broadcasts over the total area of the plot in the form of ammonium nitrate $(31 \% \mathrm{~N})$. Since there is no precise definition of the phenological stages for tropical forage grasses, the timing of the $\mathrm{N}$ application in the RP was defined when the reproductive structures were visible by dissection of the tiller. In 'Mombaça', topdressing $\mathrm{N}$ fertilizations were performed on 03/01/2013, at 33 days after emergence (DAE), in the VP, and 04/22/2013 (85 DAE), in the RP. In 'Xaraés', topdressing $\mathrm{N}$ fertilizations were performed on 01/28/2014 (33 DAE) in the VP, and 03/21/2014 (85 DAE) in the RP. Each plot measured 5 by $30 \mathrm{~m}$, which is $150 \mathrm{~m}^{2}$ total area.

Before the implementation of the experiments, the soil was conventionally prepared using a disk plow, leveling harrow, and soil compacting roller to level the soil, which are practices used in seed production fields in the first cultivation season. 'Mombaça' was sown on $01 / 20 / 2013$, with $2.5 \mathrm{~kg} \mathrm{ha}^{-1}$ pure seed, while 'Xaraés' was sown on 12/17/2013, with $3 \mathrm{~kg} \mathrm{ha}^{-1}$ pure seed. Both tropical forage grasses were sown at $0.90 \mathrm{~m}$ spacing between rows, using category $\mathrm{C} 2$ certified seed. The tropical forage grasses were fertilized during sowing with $300 \mathrm{~kg} \mathrm{ha}^{-1}$ of $\mathrm{N}-\mathrm{P}_{2} \mathrm{O}_{5}-\mathrm{K}_{2} \mathrm{O}$ 0430-10. The emergence of 'Mombaça' and 'Xaraés' occurred 7 and 9 days after sowing, respectively. During the experiments, the herbicides imazetapir (84.8 $\mathrm{g}$ a.i. $\left.\mathrm{ha}^{-1}\right)$ and 2,4-D (1,4 $\mathrm{g}$ a.i. ha $\left.{ }^{-1}\right)$ were used to control the monocotyledonous and the dicotyledonous weeds, respectively.

At the flowering stage, 30 diagnostic leaves (flag leaf) were collected from each plot. The samples were dried in a forced-air ventilation oven at $65^{\circ} \mathrm{C}$ for 72 hours, and ground. Analyses were performed to determine the concentrations of $\mathrm{N}, \mathrm{P}, \mathrm{K}, \mathrm{Ca}, \mathrm{Mg}$, and S (Malavolta et al., 1997). After natural seed drop occurred (physiological maturity), the tropical forage grasses were cut (manual cutting of the aboveground DM) with subsequent sorting of the aboveground residual straw for seed harvest. The cuts were conducted on 06/11/2013 (135 DAE) and 06/30/2014 (186 DAE), and seed were harvested on 06/22/2013 (146 DAE) and 07/04/2014 (190 DAE), for the 'Mombaça' and 'Xaraés', respectively. The aboveground residual straw was evaluated on the day the tropical forage grasses were cut. The aboveground residual straw was collected from plants of two subsamples of $1.5 \mathrm{~m}$ row per plot, which were then washed to remove the mineral impurities, oven-dried at $65^{\circ} \mathrm{C}$ for 72 hours and weighed to determine the aboveground residual straw. Subsequently, these samples were ground and evaluated for the concentrations of $\mathrm{N}, \mathrm{P}, \mathrm{K}, \mathrm{Ca}, \mathrm{Mg}$, and $\mathrm{S}$ (Malavolta et al., 1997). The accumulation of $\mathrm{N}$, $\mathrm{P}, \mathrm{K}, \mathrm{Ca}, \mathrm{Mg}$, and $\mathrm{S}$ in the aboveground residual straw was calculated by multiplying its mass $\left(\mathrm{g} \mathrm{kg}^{-1}\right.$ of $\left.\mathrm{DM}\right)$ and the concentration of each nutrient in it.

Seed yield (pure seed) was determined by harvesting seed of two subsamples of $6.0 \mathrm{~m}^{2}$ per plot.

Table 1. Soil chemical characteristics at $0-20 \mathrm{~cm}$ depth, determined before the beginning of the experiments.

\begin{tabular}{|c|c|c|c|c|c|c|c|c|c|}
\hline Experiment & $\begin{array}{c}\mathrm{pH} \\
\left(\mathrm{CaCl}_{2}\right)\end{array}$ & $\begin{array}{c}\mathrm{SOM} \\
\left(\mathrm{g} \mathrm{dm}^{-3}\right)\end{array}$ & $\begin{array}{c}\mathrm{P}_{\text {resin }} \\
\left(\mathrm{mg} \mathrm{dm}^{-3}\right)\end{array}$ & $\begin{array}{r}\mathrm{H}+\mathrm{Al} \\
----\end{array}$ & $\mathrm{K}$ & $\begin{array}{c}\mathrm{Ca} \\
\mathrm{ool}_{\mathrm{c}} \mathrm{d}\end{array}$ & $\mathrm{Mg}$ & CEC & $\begin{array}{c}\text { Base saturation } \\
(\mathrm{V}, \%)\end{array}$ \\
\hline Megathyrsus maximus 'Mombaça' & 5.8 & 10.3 & 46.7 & 11 & 2.9 & 26 & 8 & 48 & 77 \\
\hline Urochloa brizantha 'Xaraés' & 5.2 & 9.2 & 37.4 & 18 & 2.3 & 22 & 8 & 50 & 65 \\
\hline
\end{tabular}


The aboveground residual straw was removed from the harvest areas, and seed of this area were swept with a brush to enable the collection of fallen seeds in the soil. There is little published data on seed production that include seed of forage grasses that had fallen into the soil. The determination of fallen seed in the soil quantifies better the seed yield and is highly relevant for the areas harvested with the method known as sweeping, currently predominant in Brazil. Subsequently, seed were transferred to a set of screens to remove the soil and impurities. Two subsamples of each plot were mixed for each sample composition per plot, which was taken to the seed laboratory to quantify the percentage of germination, and the percentage of viable seed, using the tetrazolium test and pure seed (Brasil, 2009). The latter was used to calculate the yield of pure seed with the moisture corrected to 120 $\mathrm{g} \mathrm{kg}^{-1}$.

Nitrogen use efficiency (NUE) was defined as the increase of the yield of pure seed per unit of applied N, and calculated according to Ma \& Herath (2016), as: NUE (seed mass increase in $\mathrm{kg} \mathrm{kg}^{-1}$ of applied $\mathrm{N}$ ) = $\left(\mathrm{Y}_{\mathrm{N}}-\mathrm{Y}_{0}\right) / 150$, in which: $\mathrm{Y}_{\mathrm{N}}$ is seed yield with 150 $\mathrm{kg} \mathrm{ha}^{-1} \mathrm{~N}$; and $\mathrm{Y}_{0}$ is seed yield without topdressing $\mathrm{N}$ fertilization.

The data obtained in each experiment were separately subjected to analyses of variance. Treatment means were compared using the Tukey's test, at 5\% probability. The data were analyzed using the Sisvar statistical software package (Ferreira, 2011).

\section{Results and Discussion}

The topdressing $\mathrm{N}$ fertilization influenced the concentrations of $\mathrm{N}$ only in the flag leaf of 'Mombaça' and 'Xaraés' (Table 2). The $\mathrm{N}$ application increased the concentration of this nutrient in the flag leaf of both tropical forage grass species, however there was no variation for $\mathrm{N}$ application time. Manarim \& Monteiro (2002) observed an increase of $\mathrm{N}$ concentration in the aboveground of 'Mombaça' as a consequence of increased $\mathrm{N}$ concentrations in the nutrient solution. In general, the nutrient concentrations in the flag leaf of tropical forage grasses were within the range considered adequate for forage production in all treatments. According to Werner et al. (1997), the adequate range of $\mathrm{N}$ concentrations in $M$. maximus for forage production are $15.0-25.0 \mathrm{~g} \mathrm{~kg}^{-1} \mathrm{~N}, 1.0-3.0 \mathrm{~g} \mathrm{~kg}^{-1}$
P, $15.0-30.0 \mathrm{~g} \mathrm{~kg}^{-1} \mathrm{~K}, 3.0-8.0 \mathrm{~g} \mathrm{~kg}^{-1} \mathrm{Ca} ; 1.5-5.0 \mathrm{~g} \mathrm{~kg}^{-1}$ $\mathrm{Mg}$, and $1.0-3.0 \mathrm{~g} \mathrm{~kg}^{-1} \mathrm{~S}$. For U. brizantha, the ranges are $13.0-20.0 \mathrm{~g} \mathrm{~kg}^{-1} \mathrm{~N}, 0.8-3.0 \mathrm{~g} \mathrm{~kg}^{-1} \mathrm{P} ; 12.0-30.0 \mathrm{~g} \mathrm{~kg}^{-1}$ $\mathrm{K} ; 3.0-6.0 \mathrm{~g} \mathrm{~kg}^{-1} \mathrm{Ca} ; 1.5-4.0 \mathrm{~g} \mathrm{~kg}^{-1} \mathrm{Mg}$, and $0.8-2.5 \mathrm{~g}$ $\mathrm{kg}^{-1} \mathrm{~S}$. Adequate ranges of nutrient concentrations for tropical forage grasses grown for seed production have not been determined. Therefore, although comparisons were made for nutrient concentrations in the flag leaf of tropical forage grasses grown for fodder production, in which the vegetative growth of the plant is vigorous, it is important to emphasize that the adequate concentrations of nutrients in the flag leaf may differ for seed production. The adequate concentrations of $\mathrm{N}$ in the flag leaf, even in the treatment without the topdressing $\mathrm{N}$ fertilization, may have occurred due to soil preparation, which may have caused increases of the $\mathrm{N}$ mineral concentrations in the soil solution due to the mineralization of soil organic matter, since it turns the soil more oxidative and favors this process (Matias et al., 2009). Appropriate concentrations of $\mathrm{P}$, $\mathrm{K}, \mathrm{Ca}, \mathrm{Mg}$, and $\mathrm{S}$ occurred due to the availability of

Table 2. Nutrient (N, P, K, Ca, Mg, and S) concentrations in the flag leaf of two tropical forage grass species, as a result of the fractionation of nitrogen fertilizer application ${ }^{(1)}$.

\begin{tabular}{|c|c|c|c|c|c|c|}
\hline \multirow{3}{*}{$\begin{array}{l}\text { Nitrogen } \\
\text { manage- } \\
\text { ment }^{(2)}\end{array}$} & $\mathrm{N}$ & $\mathrm{P}$ & K & $\mathrm{Ca}$ & $\mathrm{Mg}$ & $\mathrm{S}$ \\
\hline & & & $-\alpha$ & & & \\
\hline & \multicolumn{6}{|c|}{ Megathyrsus maximus 'Mombaça' - 2013} \\
\hline No & $24.3 b$ & $2.8 \mathrm{a}$ & $15.9 \mathrm{a}$ & $8.0 \mathrm{a}$ & $3.8 \mathrm{a}$ & $1.8 \mathrm{a}$ \\
\hline N150-0 & $30.5 \mathrm{a}$ & $2.9 \mathrm{a}$ & $17.0 \mathrm{a}$ & $7.6 \mathrm{a}$ & $4.0 \mathrm{a}$ & $2.1 \mathrm{a}$ \\
\hline N0-150 & $30.6 \mathrm{a}$ & $3.1 \mathrm{a}$ & $18.0 \mathrm{a}$ & $7.1 \mathrm{a}$ & $4.0 \mathrm{a}$ & $2.1 \mathrm{a}$ \\
\hline N100-50 & $30.7 \mathrm{a}$ & $3.2 \mathrm{a}$ & $18.1 \mathrm{a}$ & $7.8 \mathrm{a}$ & $4.6 \mathrm{a}$ & $2.3 \mathrm{a}$ \\
\hline N50-100 & $39.2 \mathrm{a}$ & $3.0 \mathrm{a}$ & $16.8 \mathrm{a}$ & $7.1 \mathrm{a}$ & $4.1 \mathrm{a}$ & $1.7 \mathrm{a}$ \\
\hline \multirow[t]{2}{*}{ CV (\%) } & 10.4 & 6.6 & 12.3 & 20.2 & 17.6 & 15.9 \\
\hline & \multicolumn{6}{|c|}{ Urochloa brizantha 'Xaraés' - 2013/2014 } \\
\hline No & $15.7 \mathrm{~b}$ & $1.6 \mathrm{a}$ & $17.6 \mathrm{a}$ & $4.5 \mathrm{a}$ & $5.3 \mathrm{a}$ & $0.8 \mathrm{a}$ \\
\hline N150-0 & $19.1 \mathrm{ab}$ & $2.3 \mathrm{a}$ & $23.2 \mathrm{a}$ & $3.3 \mathrm{a}$ & $4.1 \mathrm{a}$ & $1.1 \mathrm{a}$ \\
\hline N0-150 & $19.4 \mathrm{ab}$ & $2.1 \mathrm{a}$ & $23.7 \mathrm{a}$ & $3.4 \mathrm{a}$ & $3.6 \mathrm{a}$ & $1.1 \mathrm{a}$ \\
\hline N100-50 & $20.0 \mathrm{a}$ & $2.2 \mathrm{a}$ & $22.3 \mathrm{a}$ & $3.5 \mathrm{a}$ & $3.9 \mathrm{a}$ & $1.1 \mathrm{a}$ \\
\hline N50-100 & $20.1 \mathrm{a}$ & $1.9 \mathrm{a}$ & $19.1 \mathrm{a}$ & $3.7 \mathrm{a}$ & $5.5 \mathrm{a}$ & $1.0 \mathrm{a}$ \\
\hline$\overline{C V}(\%)$ & 10.5 & 14.7 & 16.1 & 24.3 & 20.2 & 17.8 \\
\hline
\end{tabular}

${ }^{(1)}$ Means followed by different letters, in the columns, are significantly different by he Tukey's test, at $5 \%$ probability. ${ }^{(2)} \mathrm{N} 0$, without $\mathrm{N}$ fertilization; N150-0, $150 \mathrm{~kg} \mathrm{ha}^{-1} \mathrm{~N}$ at the vegetative phase; N0-150, $150 \mathrm{~kg} \mathrm{ha}^{-1} \mathrm{~N}$ between panicle initiation and prebooting stages; $\mathrm{N} 100-50,100 \mathrm{~kg} \mathrm{ha}^{-1} \mathrm{~N}$ at the vegetative phase, plus $50 \mathrm{~kg} \mathrm{ha}^{-1} \mathrm{~N}$ between panicle initiation and prebooting stages; $\mathrm{N} 50-100,50 \mathrm{~kg} \mathrm{ha}^{-1} \mathrm{~N}$ at the vegetative phase, plus 100 $\mathrm{kg} \mathrm{ha}^{-1} \mathrm{~N}$ between panicle initiation and prebooting stages. 
these nutrients in the soil, and their absorption by the tropical forage grasses (Tables 1 and 2).

The application of $150 \mathrm{~kg} \mathrm{ha}^{-1} \mathrm{~N}$ at the VP provided the highest amount of aboveground residual straw DM of 'Mombaça', but without differing from the other treatments with the topdressing $\mathrm{N}$ application (Table 3). Nitrogen has vital functions for plants, which are primarily related to their vegetative growth (Marschner, 2012). Barth Neto et al. (2010) also reported an increase of the aboveground DM using 'Mombaça' in response to $\mathrm{N}$ application. No increase of 'Xaraés' was observed for the aboveground residual straw as a consequence of $\mathrm{N}$ application. In contrast to this result, Costa et al. (2009) obtained increases of the aboveground DM of 'Xaraés' by the application of $\mathrm{N}$ in a greenhouse study.

The $\mathrm{N}$ concentrations in the residual straw of the forages increased as a consequence of the topdressing $\mathrm{N}$ fertilization, regardless of the $\mathrm{N}$ application time (Table 3). These results are similar to those obtained for the $\mathrm{N}$ concentration in the flag leaf, and show that there was a higher- $\mathrm{N}$ absorption by the plants that received the application of this nutrient (Tables 2 and 3 ). Increases of $\mathrm{N}$ concentrations in the residual straw of 'Mombaça' and 'Xaraés' were also obtained in studies reported by Manarim \& Monteiro (2002) and Costa et al. (2009). There was no effect of the management of $\mathrm{N}$ fertilization on the concentrations of $\mathrm{P}, \mathrm{K}, \mathrm{Ca}, \mathrm{Mg}$, and $\mathrm{S}$ in the residual straw of both tropical forage grasses (Table 3).

Nitrogen fertilization increased the accumulation of $\mathrm{N}, \mathrm{P}$, and $\mathrm{K}$ in the aboveground residual straw of 'Mombaça', and the accumulation only of $\mathrm{N}$ in the aboveground residual straw of 'Xaraés', but had no effect on the timing of the $\mathrm{N}$ application (Table 3). Thus, in the average of the $\mathrm{N}$ treatments, 'Mombaça' accumulated $261 \mathrm{~kg} \mathrm{ha}^{-1} \mathrm{~N}, 31 \mathrm{~kg} \mathrm{ha}^{-1} \mathrm{P}$, and $277 \mathrm{~kg} \mathrm{ha}^{-1} \mathrm{~K}$ in the aboveground residual straw, while in the treatment without the application of $\mathrm{N}$, the accumulation of these nutrients were 176,24 , and $216 \mathrm{~kg} \mathrm{ha}^{-1}$, respectively. The average increase of $48 \%$ in the accumulation of $\mathrm{N}$ in the aboveground residual straw of 'Mombaça', provided by the topdressing $\mathrm{N}$ fertilization, is related to the greater aboveground residual straw and $\mathrm{N}$ concentration (Table 3). The average increase of $28 \%$ in the accumulations of $\mathrm{P}$ and $\mathrm{K}$ in the aboveground residual straw of 'Mombaça' is attributed to the effect of the topdressing $\mathrm{N}$ fertilization on the aboveground residual straw. In 'Xaraés', the treatment without the application of $\mathrm{N}(\mathrm{N} 0)$ provided an accumulation of 82

Table 3. Aboveground residual straw and concentration and accumulation of nutrients (N, P, K, Ca, Mg, and $\mathrm{S}$ ) in the aboveground residual straw of seed production of two tropical forage grass species, as a result of the fractionation of nitrogen fertilizer application ${ }^{(1)}$.

\begin{tabular}{|c|c|c|c|c|c|c|c|c|c|c|c|c|c|}
\hline \multirow{2}{*}{$\begin{array}{l}\text { Nitrogen } \\
\text { management }^{(2)}\end{array}$} & \multirow{2}{*}{$\begin{array}{l}\text { Residual straw } \\
\quad\left(\mathrm{kg} \mathrm{ha}^{-1}\right)\end{array}$} & \multicolumn{6}{|c|}{ Nutrient concentration in the residual straw $\left(\mathrm{g} \mathrm{kg}^{-1}\right)$} & \multicolumn{6}{|c|}{ Nutrient accumulation in residual straw $\left(\mathrm{kg} \mathrm{ha}^{-1}\right)$} \\
\hline & & $\mathrm{N}$ & $\mathrm{P}$ & $\mathrm{K}$ & $\mathrm{Ca}$ & $\mathrm{Mg}$ & $\mathrm{S}$ & $\mathrm{N}$ & $\mathrm{P}$ & $\mathrm{K}$ & $\mathrm{Ca}$ & $\mathrm{Mg}$ & $\mathrm{S}$ \\
\hline & \multicolumn{13}{|c|}{ Megathyrsus maximus 'Mombaça' - 2013} \\
\hline N0 & $12,434 b$ & $14.3 b$ & $2.0 \mathrm{a}$ & $17.3 \mathrm{a}$ & $5.0 \mathrm{a}$ & $5.1 \mathrm{a}$ & $1.0 \mathrm{a}$ & $176.2 b$ & $24.3 b$ & $216.1 b$ & $62.9 \mathrm{a}$ & $64.1 \mathrm{a}$ & $12.6 \mathrm{a}$ \\
\hline N150-0 & $15,035 \mathrm{a}$ & $17.4 \mathrm{ab}$ & $2.1 \mathrm{a}$ & $18.9 \mathrm{a}$ & $4.6 \mathrm{a}$ & $5.3 \mathrm{a}$ & $1.3 \mathrm{a}$ & $260.9 \mathrm{a}$ & $32.2 \mathrm{a}$ & $283.7 \mathrm{ab}$ & $68.2 \mathrm{a}$ & $79.8 \mathrm{a}$ & $19.1 \mathrm{a}$ \\
\hline N0-150 & $13,274 \mathrm{ab}$ & $19.0 \mathrm{a}$ & $2.3 \mathrm{a}$ & $20.0 \mathrm{a}$ & $4.1 \mathrm{a}$ & $5.3 \mathrm{a}$ & $1.3 \mathrm{a}$ & $254.9 \mathrm{a}$ & $30.6 \mathrm{ab}$ & $264.1 \mathrm{ab}$ & $54.1 \mathrm{a}$ & $69.7 \mathrm{a}$ & $16.6 \mathrm{a}$ \\
\hline $\mathrm{N} 100-50$ & $14,147 \mathrm{ab}$ & $19.0 \mathrm{a}$ & $2.4 \mathrm{a}$ & $20.5 \mathrm{a}$ & $4.8 \mathrm{a}$ & $5.5 \mathrm{a}$ & $1.2 \mathrm{a}$ & $268.7 \mathrm{a}$ & $33.4 \mathrm{a}$ & $289.6 \mathrm{a}$ & $69.3 \mathrm{a}$ & $78.0 \mathrm{a}$ & $16.5 \mathrm{a}$ \\
\hline N50-100 & $13,572 \mathrm{ab}$ & $19.2 \mathrm{a}$ & $2.2 \mathrm{a}$ & $19.8 \mathrm{a}$ & $4.1 \mathrm{a}$ & $5.4 a$ & $1.0 \mathrm{a}$ & $260.2 \mathrm{a}$ & $29.3 \mathrm{ab}$ & $269.4 \mathrm{ab}$ & $55.5 \mathrm{a}$ & $73.7 \mathrm{a}$ & $14.1 \mathrm{a}$ \\
\hline \multirow[t]{2}{*}{ CV (\%) } & 6.5 & 10.1 & 8.9 & 9.3 & 33.6 & 11.5 & 20.5 & 11.9 & 10.6 & 11.3 & 24.1 & 12.5 & 20.8 \\
\hline & \multicolumn{13}{|c|}{ Urochloa brizantha 'Xaraés' - 2013/2014 } \\
\hline N0 & $12,646 \mathrm{a}$ & $6.5 b$ & $1.3 \mathrm{a}$ & $27.0 \mathrm{a}$ & 6.9 & $5.9 \mathrm{a}$ & $0.4 \mathrm{a}$ & $81.5 b$ & $16.7 \mathrm{a}$ & $340.0 \mathrm{a}$ & $87.1 \mathrm{a}$ & $74.9 \mathrm{a}$ & $5.0 \mathrm{a}$ \\
\hline N150-0 & $12,796 \mathrm{a}$ & $8.9 \mathrm{a}$ & $1.3 \mathrm{a}$ & $27.1 \mathrm{a}$ & 6.0 & $5.8 \mathrm{a}$ & $0.5 \mathrm{a}$ & $112.4 \mathrm{a}$ & $16.8 \mathrm{a}$ & $343.6 \mathrm{a}$ & $76.1 \mathrm{a}$ & $74.1 \mathrm{a}$ & $6.6 \mathrm{a}$ \\
\hline N0-150 & $11,412 \mathrm{a}$ & $9.0 \mathrm{a}$ & $1.2 \mathrm{a}$ & $27.2 \mathrm{a}$ & 7.0 & $5.9 a$ & $0.5 \mathrm{a}$ & $102.9 \mathrm{a}$ & $14.1 \mathrm{a}$ & $309.2 \mathrm{a}$ & $79.0 \mathrm{a}$ & $66.9 \mathrm{a}$ & $6.0 \mathrm{a}$ \\
\hline N100-50 & $12,322 \mathrm{a}$ & $8.9 \mathrm{a}$ & $1.3 \mathrm{a}$ & $26.7 \mathrm{a}$ & 6.7 & $6.8 \mathrm{a}$ & $0.5 \mathrm{a}$ & $109.1 \mathrm{a}$ & $16.6 \mathrm{a}$ & $328.8 \mathrm{a}$ & $81.3 \mathrm{a}$ & $83.2 \mathrm{a}$ & $6.1 \mathrm{a}$ \\
\hline N50-100 & $12,565 \mathrm{a}$ & $8.0 \mathrm{a}$ & $1.3 \mathrm{a}$ & $27.7 \mathrm{a}$ & 6.9 & $6.5 \mathrm{a}$ & $0.5 \mathrm{a}$ & $103.5 \mathrm{a}$ & $16.7 \mathrm{a}$ & $355.2 \mathrm{a}$ & $89.9 a$ & $84.4 \mathrm{a}$ & $6.4 \mathrm{a}$ \\
\hline $\mathrm{CV}(\%)$ & 24.8 & 7.9 & 14.8 & 8.3 & 23.7 & 22.8 & 22.7 & 7.8 & 17.8 & 10.8 & 24.0 & 23.3 & 20.7 \\
\hline
\end{tabular}

Pesq. agropec. bras., Brasília, v.54, e00114, 2019

DOI: 10.1590/S1678-3921.pab2019.v54.00114 
$\mathrm{kg} \mathrm{ha}^{-1}$, while the average of the treatments with the topdressing $\mathrm{N}$ application accumulated $31 \%$ more, that is, $107 \mathrm{~kg} \mathrm{ha}^{-1}$ (Table 3). According to Werner et al. (1997), the accumulation of nutrients by plants may vary depending on the type of soil, fertilization, and the stage of plant development.

Treatment averages for other nutrients in the aboveground residual straw of 'Mombaça' were: 62 $\mathrm{kg} \mathrm{ha}^{-1} \mathrm{Ca}, 73 \mathrm{~kg} \mathrm{ha}^{-1} \mathrm{Mg}$, and $15 \mathrm{~kg} \mathrm{ha}^{-1} \mathrm{~S}$ (Table 3). 'Xaraés' accumulated $16 \mathrm{~kg} \mathrm{ha}^{-1} \mathrm{P}, 335 \mathrm{~kg} \mathrm{ha}^{-1} \mathrm{~K}, 82$ $\mathrm{kg} \mathrm{ha}^{-1} \mathrm{Ca}, 76 \mathrm{~kg} \mathrm{ha}^{-1} \mathrm{Mg}$, and $6 \mathrm{~kg} \mathrm{ha}^{-1} \mathrm{~S}$. Potassium was the most accumulated nutrient in the aboveground residual straw of the tropical forage grasses, while 'Mombaça' accumulated relatively similar amounts of $\mathrm{N}$ and $\mathrm{K}$. The accumulation of $\mathrm{K}$ in the aboveground residual straw of 'Xaraés' was three times greater than the accumulation of $\mathrm{N}$. These results indicate the high capacity of the tropical forage grasses to extract $\mathrm{K}$ from the soil, primarily $U$. brizantha 'Xaraés' (Mendonça et al., 2015). Primavesi et al. (2006) observed a high accumulation of $\mathrm{N}$ and $\mathrm{K}$ by $U$. brizantha 'Marandu', with an average accumulation of 150 and $243 \mathrm{~kg} \mathrm{ha}^{-1}$, respectively, in a forage producing $7.6 \mathrm{Mg} \mathrm{ha}^{-1} \mathrm{DM}$. In this context, in forage seed production areas where the aboveground residual straw is removed, soil fertility management should factor the extraction and removal of primarily $\mathrm{N}$ and $\mathrm{K}$, avoiding soil exhaustion, after consecutive cultivation cycles of tropical forage grasses. However, in areas where the aboveground residual straw of forages is maintained on the soil surface, the release of nutrients to crops in succession should also be considered in fertilization recommendations.

The management of $\mathrm{N}$ fertilization affected the pure seed yield of 'Mombaça' and 'Xaraés' (Table 4). The topdressing $\mathrm{N}$ application increased the pure seed yield for 'Mombaça', regardless of the $\mathrm{N}$ application time. In the case of 'Xaraés', the largest pure seed yield was obtained with the application of $50 \mathrm{~kg} \mathrm{ha}^{-1} \mathrm{~N}$ at the VP, plus $100 \mathrm{~kg} \mathrm{ha}^{-1} \mathrm{~N}$ at the RP. Increases in the seed yield of 'Mombaça' in response to $\mathrm{N}$ fertilization were obtained in an experiment conducted by Barth Neto et al. (2010). However, the application of $150 \mathrm{~kg} \mathrm{ha}^{-1}$ $\mathrm{N}$ at the FV resulted in a seed yield similar to that of the control (N0), in both tropical forage grasses, which may have occurred due to the high residual straw (leaves and stems) above ground. The application of $\mathrm{N}$ at the VP may have altered the source-sink ratio of both tropical forage grasses, which primarily translocated and redistributed their photoassimilates to vegetative structures (leaves and vegetative tillers) to the detriment of seed production. Nitrogen has vital functions for plants, which are primarily related to their vegetative growth (Marschner, 2012). Therefore, high rates of $\mathrm{N}$ applied in the initial stages of the development of the plants can promote increases of the production of vegetative biomass and decreases of the reproductive biomass (Peres et al., 2010), as observed in our experiment. This decrease of the reproductive biomass can reduce the pure seed yield of the tropical forage grasses and, consequently, can directly affect the profitability of tropical forage grass seed producers. The high-pure seed yields, primarily of 'Mombaça', occurred due to climatic conditions and soil fertility that were adequate for the cultivation of tropical forage grasses. In addition, the system of seed collection by sweep enabled the collection of fallen seed in the soil and avoided losses. In the studies of Barth Neto et al. (2010) and Canto et al. (2012), only seed

Table 4. Seed yield, nitrogen use efficiency (NUE), initial seed viability, and seed germination percentages of two tropical forage grass species as a result of the fractionation of nitrogen fertilizer application ${ }^{(1)}$.

\begin{tabular}{|c|c|c|c|c|}
\hline $\begin{array}{l}\text { Nitrogen } \\
\text { Management }^{(2)}\end{array}$ & $\begin{array}{l}\text { Seed yield } \\
\left(\mathrm{kg} \mathrm{ha}^{-1}\right)\end{array}$ & $\begin{array}{c}\text { NUE }(\mathrm{kg} \\
\text { seed } \mathrm{kg}^{-1} \\
\text { applied } \mathrm{N})\end{array}$ & $\begin{array}{c}\text { Initial seed } \\
\text { viability }\end{array}$ & $\begin{array}{c}\text { Seed } \\
\text { germination }\end{array}$ \\
\hline & \multicolumn{4}{|c|}{ Megathyrsus maximus 'Mombaça' - 2013} \\
\hline No & $201.5 b$ & - & $73.3 \mathrm{a}$ & $63.6 \mathrm{a}$ \\
\hline N150-0 & $235.3 \mathrm{ab}$ & 0.23 & $73.6 \mathrm{a}$ & $68.9 \mathrm{a}$ \\
\hline N0-150 & $277.9 \mathrm{a}$ & 0.51 & $80.8 \mathrm{a}$ & $66.5 \mathrm{a}$ \\
\hline $\mathrm{N} 100-50$ & $251.7 \mathrm{a}$ & 0.33 & $70.6 \mathrm{a}$ & $66.8 \mathrm{a}$ \\
\hline N50-100 & $283.2 \mathrm{a}$ & 0.54 & $71.7 \mathrm{a}$ & $63.0 \mathrm{a}$ \\
\hline \multirow[t]{2}{*}{$\mathrm{CV}(\%)$} & 14.8 & - & 13.9 & 15.6 \\
\hline & \multicolumn{4}{|c|}{ Urochloa brizantha 'Xaraés' - 2013/2014 } \\
\hline No & $225.6 \mathrm{c}$ & - & $68.5 \mathrm{a}$ & $55.5 \mathrm{a}$ \\
\hline N150-0 & $252.4 \mathrm{bc}$ & 0.18 & $70.0 \mathrm{a}$ & $58.8 \mathrm{a}$ \\
\hline N0-150 & $285.7 b$ & 0.40 & $74.5 \mathrm{a}$ & $63.8 \mathrm{a}$ \\
\hline N100-50 & $267.7 \mathrm{bc}$ & 0.28 & $75.5 \mathrm{a}$ & $60.5 \mathrm{a}$ \\
\hline N50-100 & $354.5 \mathrm{a}$ & 0.86 & $72.5 \mathrm{a}$ & $62.3 \mathrm{a}$ \\
\hline $\mathrm{CV}(\%)$ & 8.5 & - & 21.5 & 12.7 \\
\hline
\end{tabular}

(1) Means followed by different letters, in the columns, are significantly different by the Tukey's test, at $5 \%$ probability. ${ }^{(2)} \mathrm{N} 0$, without $\mathrm{N}$ fertilization; N150-0, $150 \mathrm{~kg} \mathrm{ha}^{-1} \mathrm{~N}$ at the vegetative phase; N0-150, 150 $\mathrm{kg} \mathrm{ha}^{-1} \mathrm{~N}$ between panicle initiation and prebooting stages; N100-50, $100 \mathrm{~kg} \mathrm{ha}^{-1} \mathrm{~N}$ at the vegetative phase, plus $50 \mathrm{~kg} \mathrm{ha}^{-1} \mathrm{~N}$ between panicle initiation and prebooting stages; $\mathrm{N} 50-100,50 \mathrm{~kg} \mathrm{ha}^{-1} \mathrm{~N}$ at the vegetative phase, plus $100 \mathrm{~kg} \mathrm{ha}^{-1} \mathrm{~N}$ between panicle initiation and prebooting stages. 
contained in the panicles at the time of harvest were quantified for the pure seed yield. The topdressing $\mathrm{N}$ fertilization increased the NUE in both tropical forage grasses; however, the response was more significant in the treatments with the application of all or most $\mathrm{N}$ between the panicle initiation and prebooting stages (N0-150 and N50-100) (Table 4).

The viability and seed germination of 'Mombaça' and 'Xaraés' were not increased using $\mathrm{N}$ fertilization management (Table 4). These results can be attributed to the $\mathrm{N}$ concentrations in the flag leaf because even without topdressing nitrogen fertilization showed values between the ranges considered adequate, and provided similar values for viability and germination of seed of both tropical forage grasses. However, these results are in contrast to those obtained by Barth Neto et al. (2010), who observed increases of seed germination with the $\mathrm{N}$ application.

\section{Conclusions}

1. Topdressing $\mathrm{N}$ fertilization, regardless of the $\mathrm{N}$ fractionation method, increased the $\mathrm{N}$ concentrations in the flag leaf and in the aboveground residual straw, and the $\mathrm{N}$ accumulation in the aboveground residual straw of the tropical forage grasses 'Mombaça' and 'Xaraés'.

2. The split-application of $\mathrm{N}$ fertilization (100 $\mathrm{kg} \mathrm{ha}^{-1} \mathrm{~N}$ at the vegetative phase, plus $50 \mathrm{~kg} \mathrm{ha}^{-1} \mathrm{~N}$ between the panicle initiation and prebooting stages) and $150 \mathrm{~kg} \mathrm{ha}^{-1} \mathrm{~N}$ at the vegetative phase increased the accumulation of DM, $\mathrm{P}$, and $\mathrm{K}$ in the aboveground residual straw of 'Mombaça'.

3. The split-application of $\mathrm{N}$ fertilization $\left(50 \mathrm{~kg} \mathrm{ha}^{-1}\right.$ $\mathrm{N}$ vegetative phase, plus $100 \mathrm{~kg} \mathrm{ha}^{-1} \mathrm{~N}$ between panicle initiation and prebooting stages) and $150 \mathrm{~kg} \mathrm{ha}^{-1} \mathrm{~N}$ between the panicle initiation and prebooting stages provided the highest pure seed yields and $\mathrm{N}$ use efficiency of both tropical forage grass species.

4. The physiological quality of the tropical forage grass seed was not affected by topdressing $\mathrm{N}$ fertilization.

\section{Acknowledgments}

To Fundação de Amparo à Pesquisa do Estado de São Paulo (Fapesp), for supporting this research and providing a scholarship to the first author (Grant n. $^{\circ}$ 2012/09398-4); to Fundação Agrisus, for supporting this research (Grant n. ${ }^{\circ}$ PA1095-13); to Conselho Nacional de Desenvolvimento Científico e Tecnológico (CNPq), for granting an award for excellence in research to the second author, and to the agronomist Elton Anderson Aranda (in memorium), for his collaboration in the experiments.

\section{References}

BARCELOS, A.F.; LIMA, J.A. de; PEREIRA, J.P.; GUIMARÃES, P.T.G.; EVANGELISTA, A.R.; GONÇALVES, C.C. de M. Adubação de capins do gênero Brachiaria. Belo Horizonte: Epamig, 2011. 84p.

BARTH NETO, A.; BOLETA, V.S.; PANCERA JÚNIOR, E.J.; ALMEIDA, G.M. de; CANTO, M.W. do; GASPARINO, E.; BALTAZAR, L.F. Nitrogênio e época de colheita nos componentes da produtividade de forragem e sementes de capim-mombaça. Pesquisa Agropecuária Brasileira, v.45, p.1312-1320, 2010. DOI: https://doi.org/10.1590/S0100-204X2010001100012.

BASTO, D. de C. Impacto da inversão da intensidade de desfolhação sobre o perfilhamento e adaptação estrutural em pasto de Brachiaria spp. 2014. 79p. Tese (Doutorado) - Escola Superior de Agricultura Luiz de Queiroz, Universidade de São Paulo, Piracicaba.

BATELLO, C.; BRINKMAN, R.; MANNETJE, L.T.; MARTINEZ, A.; SUTTIE, J. Plant genetic resources of forage crops, pasture and rangelands. [Rome]: FAO, 2017. 62p. Available at: <http://www.fao.org/fileadmin/templates/agphome/ documents/PGR/SoW2/thematicstudy_forage.pdf $>$. Accessed on: Apr. 302017.

BRASIL. Ministério da Agricultura, Pecuária e Abastecimento. Regras para análise de sementes. Brasília, 2009. 395p.

CANTO, M.W. do; BARTH NETO, A.; PANCERA JÚNIOR, E.J.; GASPARINO, E.; BOLETA, V.S. Produção e qualidade de sementes do capim-mombaça em função da adubação nitrogenada. Bragantia, v.71, p.430-437, 2012. DOI: https://doi.org/10.1590/S0006-87052012005000032.

CATUCHI, T.A.; COSTA, L.P.F. da; FOLONI, J.S.S.; TIRITAN, C.S.; CUSTÓDIO, C.C.; TSUHAKO, A.T. Produção e qualidade de sementes de Urochloa humidicola em razão da adubação nitrogenada e potássica. Colloquium Agrariae, v.9, p.30-42, 2013. DOI: https://doi.org/10.5747/ca.2013.v09.n2.a090.

CATUCHI, T.A.; SORATTO, R.P.; FRANCISQUINI JÚNIOR, A.; ARANDA, E.A.; GUIDORIZZI, F.V.C.; TIRITAN, C.S. Nitrogen management, nitrogen use efficiency, and seed yield and quality of creeping signalgrass. Crop Science, v.57, p.2865-2874, 2017. DOI: https://doi.org/10.2135/cropsci2017.02.0096.

CECATO, U.; GALBEIRO, S.; SOARES FILHO, C.V.; RIBEIRO, A.M.; MARI, G.C. Adubação e manejo da pastagem em sistemas intensivos de produção. In: HEINRICHS, R.; SOARES FILHO, C.V. (Ed.). Adubação e manejo de pastagem. Birigui: Boreal, 2014. p.1-35.

CEPEA. Centro de Estudos Avançados em Economia Aplicada. BOI/CEPEA: queda nos preços de forrageiras favorece reforma de pastagem. Available at: <http://www.cepea.esalq.usp.br/br/ 
releases/boi-cepea-queda-nos-precos-de-forrageiras-favorecereforma-de-pastagem.aspx>. Accessed on: Aug. 252017.

CONDÉ, A.R.; GARCIA, J. Efeito de níveis e épocas de aplicação de nitrogênio na produção e qualidade das sementes do capimcolonião. Revista Brasileira de Sementes, v.10, p.33-42, 1988. DOI: https://doi.org/10.17801/0101-3122/rbs.v10n1p33-42.

CORRÊA, L. de A.; SANTOS, P.M. Manejo e utilização de plantas forrageiras dos gêneros Panicum, Brachiaria e Cynodon. São Carlos: Embrapa Pecuária Sudoeste, 2003. 36p. (Embrapa Pecuária Sudoeste. Documentos, 34). Available at: $\quad<$ https://www.infoteca.cnptia.embrapa.br/bitstream/ doc/697407/1/Documentos340.pdf>. Accessed on: Apr. 152017.

COSTA, K.A. de P.; OLIVEIRA, I.P. de; FAQUIN, V.; SILVA, G.P.; SEVERIANO, E. da C. Produção de massa seca e nutrição nitrogenada de cultivares de Brachiaria brizantha (A. Rich) Stapf sob doses de nitrogênio. Ciência e Agrotecnologia, v.33, p.1578-1585, 2009. DOI: https://doi.org/10.1590/S141370542009000600017.

COSTA, N.R.; ANDREOTTI, M.; ULIAN, N. de A.; COSTA, B.S.; PARIZ, C.M.; TEIXEIRA FILHO, M.C.M. Acúmulo de nutrientes e tempo de decomposição da palhada de espécies forrageiras em função de épocas de semeadura. Bioscience Journal, v.31, p.818-829, 2015. DOI: https://doi.org/10.14393/BJv31n3a2015-22434.

FERREIRA, D.F. Sisvar: a computer statistical analysis system. Ciência e Agrotecnologia, v.35, p.1039-1042, 2011. DOI: https://doi.org/10.1590/S1413-70542011000600001.

IBGE. Instituto Brasileiro de Geografia e Estatística. Censo agropecuário 2006: Brasil, Grandes Regiões e Unidades da Federação. 2006. Available at: <https://biblioteca.ibge.gov.br/ visualizacao/periodicos/51/agro_2006.pdf > . Accessed on: Jan. 10 2017.

MA, B.L.; HERATH, A.W. Timing and rates of nitrogen fertiliser application on seed yield, quality and nitrogen-use efficiency of canola. Crop and Pasture Science, v.67, p.167-180, 2016. DOI: https://doi.org/10.1071/CP15069.

MALAVOLTA, E.; VITTI, G.C.; OLIVEIRA, S.A. de. Avaliação do estado nutricional das plantas: princípios e aplicações. 2.ed. Piracicaba: Potafos, 1997. 319p.

MANARIM, C.A.; MONTEIRO, F.A. Nitrogênio na produção e diagnose foliar do capim-mombaça. Boletim de Indústria Animal, v.59, p.115-123, 2002.

MARSCHNER, P. (Ed.). Marschner's mineral nutrition of higher plants. $2^{\text {nd }}$ ed. San Diego: Academic Press, 2012. 889p.

MATIAS, M. da C.B. da S.; SALVIANO, A.A.C.; LEITE, L.F. de C; ARAÚJO, A.S.F. de. Biomassa microbiana e estoques de $\mathrm{C}$ e $\mathrm{N}$ do solo em diferentes sistemas de manejo, no Cerrado do Estado do Piauí. Acta Scientiarum. Agronomy, v.31, p.517-521, 2009. DOI: https://doi.org/10.4025/actasciagron.v31i3.687.

MENDONÇA, V.Z. de; MELLO, L.M.M. de; ANDREOTTI, M.; PARIZ, C.M.; YANO, E.H.; PEREIRA, F.C.B.L. Liberação de nutrientes da palhada de forrageiras consorciadas com milho e sucessão com soja. Revista Brasileira de Ciência do Solo, v.39, p.183-193, 2015. DOI: https://doi.org/10.1590/01000683rbcs20150666.

MOREIRA, J.F.M.; COSTA, K.A.P.; SEVERIANO, E.C.; SIMON, G.A.; CRUVINEL, W.S.; BENTO, J.C. Nutrientes em cultivares de Brachiaria brizantha e estilosantes em cultivo solteiro e consorciado. Archivos de Zootecnia, v.62, p.513-523, 2013. DOI: https://doi.org/10.4321/S0004-05922013000400004.

NERY, M.C.; NERY, F.C.; SILVA, D.R.G.; SOARES, F.P. Produção de sementes forrageiras. Lavras: Ed. da UFLA, 2012. 47p. (Boletim técnico, 88).

PERES, R.M.; SOUZA, F.H.D. de; COUTINHO FILHO, J.L.V.; JUSTO, C.L. Manejo de campos de produção de sementes de Brachiaria humidicola “comum": I - Efeito de doses de nitrogênio. Boletim de Indústria Animal, v.67, p.27-34, 2010.

PRIMAVESI, A.C.; PRIMAVESI, O.; CORRÊA, L. de A.; SILVA, A.G. da; CANTARELLA, H. Nutrientes na fitomassa do capim-marandu em função de fontes e doses de nitrogênio. Ciência e Agrotecnologia, v.30, p.562-568, 2006. DOI: https://doi.org/10.1590/S1413-70542006000300024.

SANTOS, H.G. dos; JACOMINE, P.K.T.; ANJOS, L.H.C. dos; OLIVEIRA, V.A. de; LUMBRERAS, J.F.; COELHO, M.R.; ALMEIDA, J.A. de; CUNHA, T.J.F.; OLIVEIRA, J.B. de. Sistema brasileiro de classificação de solos. 3.ed. rev. e atual. Brasília: Embrapa, 2013. 353p.

SOUZA, F.H.D. de; POTT, E.B.; PRIMAVESI, O.; BERNARDI, A.C. de C.; RODRIGUES, A. de A. (Ed.) Usos alternativos de palhada residual da produção de sementes para pastagens. São Carlos: Embrapa Pecuária Sudeste, 2006. 241p.

VIANA, M.C.M.; FREIRE, F.M.; FERREIRA, J.J.; MACÊDO, G.A.R.; CANTARUTTI, R.B.; MASCARENHAS, M.H.T. Adubação nitrogenada na produção e composição química do capim-braquiária sob pastejo rotacionado. Revista Brasileira Zootecnia, v.40, p.1497-1503, 2011. DOI: https://doi.org/10.1590/S1516-35982011000700014.

WERNER, J.C.; PAULINO, V.T.; CANTARELLA, H.; ANDRADE, N. de O.; QUAGGIO, J.A. Forrageiras. In: RAIJ, B. van; CANTARELlA, H.; QUAGGIO, J.A.; FURLANI, A.M.C. (Ed.). Recomendações de adubação e calagem para o Estado de São Paulo. 2.ed. rev. e atual. Campinas: Instituto Agronômico, 1997. p. 263-273. (IAC. Boletim técnico, 100). 